\title{
EVALUATING HIGH-SPEED-RAIL SYSTEM IN BOT SCHEME BY ECONOMIC STATUS IN TAIWAN ROC
}

\author{
Chi-Lyang Shing Yu-min You
}

\author{
Construction Department at Tamkang University
}

\begin{abstract}
This is a research funded by National Science Foundation NSC 89-2815-C-032012-E

The Build - Operate - Government largely emphasizes Transfer strategy. Officials and academicians. Yet, no successful examples can be found in Taiwan until year 2000. The High - Speed - Rail. BOT system could be number one case on this island.This paper will investigate the HSR-BOT project from the following aspects:

(1) BOT and its background.

(2) Case study of international BOT projects - both successful ones and failed ones.

(3) The current economic status of Taiwan.

(4) Cost study of BOT scheme.

(5) Advantages and disadvantaged for BOT projects under current domestic situation

(6) High - Speed - Rail (HSR) in Build - Operate - Transfer (BOT) scheme for it's overall economic evaluation.

(7) Conclusion and recommendation.
\end{abstract}

This paper intends to study the BOT scheme for Taiwan High-Speed-Rail project. Some domestic and foreign project is reviewed to see both successful and failure projects and its reasons. The domestic economic status of Taiwan is also presented to evaluate the effects of HSR costs. Furthermore, the construction of HSR in Taiwan will influence the economic development of Taiwan to what extent will be studied.

Keywords: Build-Operate-Transfer, High-Speed-Rail, Cost Overrun, Schedule delay Taiwan HSR and its Costs.

The content of cost items for HSR investment will be categorized. The purpose of this is to see the change of exchange rate between New Taiwan Dollar (N.T) and U.S.D. And the delay of construction completion date may bring some impact on HSR cost. The owner's equity of HSR may face some difficulty due to it's source and timing.

The total cost of HSR is 441,900 Million NT, approximate 16,400 Million US, according to Bureau of HSR's estimate. Some past international case study showed that BOT projects with $300 \mathrm{M} \sim 1,000 \mathrm{M}$ USD stand best chance to be successful. The Taiwan HSR project exceeds that best scale by sixteen fold, the control of it's cost becomes an important issue. Special attention should be given to the loan borrowed form private sector. The basic concept of BOT is to utilize the private sector and/or private funds to facilitate the construction of public works. The misunderstanding of BOT is that public work can be carried out without spending taxpayer's money. The reality is that regardless BOT scheme or traditional government budget is used in pubic construction projects, it is only another format of government debt. In short term, BOT truly can reduce the government debt or spending. However, in long term, it only complicated the problem. How to prevent problems from very beginning is a very important issue. Project finance for BOT projects mean banks provide funds without holding a lien against some tangible property. The funds could be astronomical numbers. So the HSR commission company must provide some tangible guarantee or the government must step in to take some default risk for banks.

This paper also provides some case study -- both domestic and international BOT projects. Such as Euro-tunnel, Korean High-Speed-Rail, Bankok Elevated transportation highway projects etc. Taipei Department of Rapid Transit System (DORTS) is also analyzed to compare the similarities and differences although Taipei DORTS is not a BOT projects.

It is discovered that not only schedule delay will result in cost overrun, but also the following factors will increase total project cost:

1. Original evaluation of traffic volume is over optimistic.

2. Parallel competition from other similar projects.

3. Design change. 
4. Original planning is too rough

5. Political factors

6. Exchange rate variation is higher then expected

7. Land acquisition is delayed

At least the following methods could be adopted to improve the above:

1. Auxiliary loan provided by the government

2. Guarantee about exchange rate

3. Guarantee about minimum traffic volume

4. Prudent evaluation in early stage about planning

5. Reduce design change to a minimum level

6. While analyze competition, careful study should replace optimistic guess

7. Legislators should pass a law so government can provide corresponding guarantees.

8. Use domestically manufactured machine and equipment whenever possible, so the risk about exchange rate can be minimized

It seems to be the intention of Taiwan High-Speed - Rail Corporation to be optimistic in its financial plan. The funding resource is the key to success for this BOT project. On the surface, it needs minimum assistance from the R.O.C. Government.

Table 1 Comparison of different projects in different nations

\begin{tabular}{|c|c|c|c|c|c|}
\hline \multirow{2}{*}{$\begin{array}{l}\text { Project } \\
\text { item }\end{array}$} & \multirow[t]{2}{*}{$\begin{array}{l}\text { Euro } \\
\text { tunnel }\end{array}$} & \multirow[t]{2}{*}{$\begin{array}{c}\text { Korean } \\
\text { HSR }\end{array}$} & \multirow{2}{*}{$\begin{array}{c}\text { Thailand Highway } \\
\text { Railway } \\
\text { System }\end{array}$} & \multicolumn{2}{|c|}{$\begin{array}{c}\text { Taipei DORTS } \\
\text { (not BOT scheme) }\end{array}$} \\
\hline & & & & Mucha line & Tamsui line \\
\hline $\begin{array}{l}\text { Construction } \\
\text { period }\end{array}$ & 1987-1993 & 1989-1998 & 1990-1998 & $1988-1991$ & 1988-1992 \\
\hline $\begin{array}{l}\text { Scheduled } \\
\text { or } \\
\text { Actual } \\
\text { operation }\end{array}$ & $\begin{array}{l}1994 \\
\text { April }\end{array}$ & 2005 & $\begin{array}{c}1999 \\
\text { December }\end{array}$ & 1996 March & 1997 March \\
\hline $\begin{array}{l}\text { Predicted } \\
\text { or } \\
\text { Actual } \\
\text { Delay }\end{array}$ & 4 month & 7Years & 1Year & 5Year & 5Year \\
\hline $\begin{array}{l}\text { Original } \\
\text { Amount }\end{array}$ & 78 Million US & 64 Million US & 32 Million US & $\begin{array}{l}169 \text { Million } \\
\text { NT } \\
\text { (Land } \\
\text { excluded) }\end{array}$ & $\begin{array}{l}411 \text { Million NT } \\
\text { (Land excluded) }\end{array}$ \\
\hline Actual Amount & 170 Million US & 196 Million US & 40 Million US & $\begin{array}{l}198 \text { Million } \\
\text { NT } \\
\text { (Land } \\
\text { excluded) }\end{array}$ & $\begin{array}{l}\text { 428 Million NT } \\
\text { (Land excluded) }\end{array}$ \\
\hline $\begin{array}{l}\text { Overrun } \\
\text { Amount }\end{array}$ & 92 Million US & 132 Million US & 8 Million US & 29 Million NT & 17 Million NT \\
\hline
\end{tabular}

Exchange Rate and its Impact
In 1997, the explosion of Asian Financial Crisis make the exchange rate of NTD to US jumped from 26.26 to 32.62 . In other words, the NT lost 
6.36 within 5-year period. It is disadvantageous to HSR project in Taiwan due to large amount of imported equipment and facilities. Furthermore, after Asian Financial Crisis, private sector in Taiwan lost its confidence in long - term loan so High-Speed -Rail Corporation faces more obstacles to raise funds. There are several more factors will effect Taiwanese economy:

1. Development of international situationboth political and economical

2. Domestic financial problems and its development

3. The ability of government to carry out public construction projects

4. Cross - Taiwan-strait relationship and its effects

Hopefully, there will be another peak period for public work investment in Taiwan construction market in the near future.

The economical development is restrained by existing traffic system. It is extremely difficult to make further expansion. High-Speed-Rail must take over future traffic volume.

The total length of HSR-- Taiwan is 345 Kilometers. The special privilege period is 35 year for railway and station real-estate projects have 50 year. Total 11 stations are planned. The investment of HSR corporation including Civil/Architecture structure, Electrical/Mechanical facilities, rail system, station and its vicinity area development. This paper will divide all costs into two categories -domestic costs and imported facilities costs. There imported facilities cost will be affected by exchange rate. Originally, Bureau of HSR used
$1 \mathrm{US} \$=27.5 \mathrm{NTD} \$$ to calculate the costs. But now, it seems to be closer to 1US\$=30.8NTD\$. The imported facilities costs will increase 19,343 million NTD. As far as construction is concerned, up until now, not much is completed. We can say it is unlikely that this project will be completed within three years as originally planned. Therefore, this study will use 5-year as delayed schedule. It is calculated by the average delayed time of Taipei MRT. The following basic assumptions are also adopted:

(1) Mucha line and Tamsui line of DORTS average delayed time for HSR delayed schedule Inflation rate use $3.5 \%$ annually (from Bureau of HSR)

Nominal discount rate $12 \%$ (from Bureau of HSR)

Use 2003 as the final value year. Total cost is used for comparison of original cost and delayed cost. According to Bureau of HSR, it is calculated that total cost is NT441, 919 million and final value for year 2003 is 655,837 million. But because of the delay of 5 year for completion, the final value of 2003 is reduced to NT 435,594 million. Therefore, it is estimated that 5-year delay will reduce total value 220,243 million in its net income. (Which equals operation revenue plus station development income minus maintenance cost), it is also reduced for 53,905 million due to 5-year delay. Total net income is reduced from 278,723 million to 224,818 million

Table 2 HRS cost estimate (Million NTD)

(Source: Bureau of HSR)

\begin{tabular}{||c|c|c|c|c|}
\hline Year & Cost & $\begin{array}{c}2003 \\
\text { Final } \\
\text { Value }\end{array}$ & $\begin{array}{c}5 \text { year } \\
\text { extension } \\
\text { inflation }\end{array}$ & $\begin{array}{c}2003 \\
\text { Final } \\
\text { Value }\end{array}$ \\
\hline $1990.7 .1 \sim 95.1 .1$ & 3474 & 11817 & 0 & 0 \\
\hline $1995.7 .1 \sim 99.1 .1$ & 202535 & 365966 & 4029 & 7702 \\
\hline $2000.7 .1 \sim 2005.1 .1$ & 235910 & 278054 & 195030 & 206158 \\
\hline $2005.7 .1 \sim 2010.1 .1$ & 0 & 0 & 326582 & 221014 \\
\hline Total & 441919 & 655837 & 525641 & 435594 \\
\hline
\end{tabular}

Schedule Delay and Cost Influence Originally, self-sufficient payment is $42.5 \%$ if the completion date is July 2003. However, if the schedule is delayed for five years, the rate 
becomes 51.6\%. This is unreasonable. After in-- depth. Study, it is concluded that the $12 \%$ discount rate is too high. The five-year delay saved high amount of interest expenses. For the same period, the lost revenue is much lower than interest. This is a major pitfall in cost analysis of HSR . Taiwan High-Speed-Rail Corporation is composed of two foreign companies and five domestic companies.

The two foreign companies are Siemens from Germany and G.E. Alshthom from France .
They are primarily responsible for Electrical/Mechanical system including rolling stock. The latest news is that these two foreign companies maybe replaced by other Japanese companies. The domestic five companies are Continental Engineering Corporation, TongYuan Electrical Group, Pacific wire Group, Evergreen Group, Fu-Bon Insurance Group. Their assets and investment percentage are listed in Table 3. Total cost distribution for HSR is listed in Table 4

Table 3 Domestic Company and its Assets

(Source: Tien-Sha Magazine, May 1999)

\begin{tabular}{|c|c|c|c|c|}
\hline \hline & $\begin{array}{c}\text { NET } \\
\text { worth } \\
(100 \mathrm{M} . \mathrm{NT})\end{array}$ & $\begin{array}{c}\text { Percent } \\
\text { Of } \\
\text { Investment } \\
10(\%)\end{array}$ & $\begin{array}{c}\text { Percent } \\
\text { Of } \\
\text { Investment } \\
20(\%)\end{array}$ & $\begin{array}{c}\text { Percent } \\
\text { Of } \\
\text { Investment } \\
25(\%)\end{array}$ \\
\hline Continental & 148.78 & 14.878 & 29.756 & 37 \\
\hline Tong--Yuan & 352.2 & 35.22 & 70.44 & 88.05 \\
\hline $\begin{array}{c}\text { Pacific } \\
\text { Wire }\end{array}$ & 365.95 & 36.595 & 73.19 & 91.488 \\
\hline $\begin{array}{c}\text { Evergreen } \\
\text { Fubon }\end{array}$ & 750.55 & 75.055 & 150.11 & 187.5 \\
\hline Total Asset & 2251.6 & 225.16 & 450.32 & 158.53 \\
\hline
\end{tabular}

Table 4 HSR Total cost and share percentage (Source: HSR Bureau)

\begin{tabular}{||c|c|}
\hline Total investment 441.9 billion NT & Percentage share (\%) \\
\hline Government share 106 billion NT & 24 \\
\hline Government capital assisted 116.3 billion NT & 26.3 \\
\hline Private share 219.6 billion NT & 49.7 \\
\hline
\end{tabular}




\begin{tabular}{|c|c|}
\hline Private investment 219.6 billion NT & Percentage share (\%) \\
\hline Debt loan 146.7 billion NT & 75 \\
\hline Shareholder loan 54.9 billion NT & 25 \\
\hline
\end{tabular}

\section{Conclusion and Recommendation}

The following conclusion could be drawn

1. Korean High-Speed-Rail project can give us lots of lessons to learn. Especially political intervention and design change resulted in schedule delay can and should be analyzed in great detail so similar mistakes will not occur in Taiwan HSR

2. Assuming inflation rate is $3.5 \%$, discount rate is $12 \%$ constant. This research indicated that 5year delay is beneficial to the entire project. Therefore, it is recommended that $12 \%$ discount rate should be investigated further to justify its appropriateness

3. The Government has committed this huge debt/loan guarantee program. In order to have some stability for the commitment. It is recommended some type of legislative procedures should be induced for Taiwan HSR. Therefore, the Executive branch of government will not change its policy due to change of political party

\section{Acknowledgments}

This paper is part of a research funded by National Science Foundation NSC-892 grants. The support of NSF is highly appreciated

\section{REFERENCE}

1. Taiwan High Speed Rail Net http://210.65.184.232/

2. Shing, Chi-Lyang and Young, Chung-Tse "Case study of Taiwan HSR and BOT system. " Modern Construction, No.230, February, 1999

3. Shing, Chi-Lyang, "Theory and practice of construction management," Construction News Records, No 80, Taipei, Taiwan, R.O.C. OCT.1988, PP55 PP66.

4. Shing, Chi-Lyang, "Contract change order in public construction projects". Chinese Engineers Journals, No 67-8, Taipei, Taiwan, R.O.C, Aug, 1994, PP3 PP6 